Article

\title{
Determination and Review of Physical and Mechanical Properties of Raw and Treated Coconut Fibers for Their Recycling in Construction Materials
}

\author{
Huyen Bui ${ }^{1,2}$, Nassim Sebaibi ${ }^{1}$, , Mohamed Boutouil ${ }^{1}$ and Daniel Levacher ${ }^{3, *}$ \\ 1 Laboratoire ESITC-ESITC Caen, ComUE Normandie Université, 14160 Epron, France; \\ huyen.bui@esitc-caen.fr (H.B.); nassim.sebaibi@esitc-caen.fr (N.S.); mohamed.boutouil@esitc-caen.fr (M.B.) \\ 2 Faculty of Civil Engineering, Thuyloi University, 175 Tay Son Street, Dong Da District, Ha Noi 116705, \\ Vietnam \\ 3 M2C UMR 6143 CNRS, Unicaen, ComUE Normandie Université, 24 rue des Tilleuls, 14000 Caen, France \\ * Correspondence: daniel.levacher@unicaen.fr; Tel.: +33-633-536-694
}

Received: 5 April 2020; Accepted: 22 May 2020; Published: 12 June 2020

\begin{abstract}
In order to reduce the dependency on conventional materials and negative environmental impacts, one of the main responsibilities of the construction field is to find new eco-friendly resources to replace the traditional materials partially. Natural fibers were known as potential candidates for the reinforcement of structures in civil engineering by virtue of their advantages. Among the different kinds of vegetable fibers, coconut fiber has been exploited in a limited way over the past few years. This paper aims at evaluating the different properties of local coconut fibers (Vietnam). Several laboratory tests provide geometrical, physical, mechanical properties and durability properties that are compared with literature results obtained from similar natural fibers. The local coconut fibers tested demonstrated properties suitable for reinforced mortars. With adequate control of their preparation, they could be reused in the manufacture of mortars in the construction.
\end{abstract}

Keywords: coconut fiber; geometrical properties; physical properties; mechanical properties; durability

\section{Introduction}

The usage of green materials in construction activities has become very interesting in recent years due to its advantages in different sectors. Many studies have shown the possible uses of natural fiber, such as the partial replacement of cement and aggregate, as well as fiber reinforcement [1-6]. Coconut fiber was known as one of main fifteen plant and animal fibers in the world [7]. This fiber has a high concentration of lignin among vegetable fibers, up to nearly $50 \%$, which makes it stronger [8]. Coconut fiber is extracted from the tissues surrounding the envelope of the coconut palm, which is grown on 10 million ha of land throughout the tropics. According to the Food and Agriculture Organization of the United Nations FAO [9], five countries ranked at the top positions in the world for producing coconut fiber are India, Sri Lanka, Thailand, Vietnam, and Philippines. These countries produce more than 90 percent of the global coconut fiber production. Coconut fiber is commonly utilized in ropes, mattresses, brushes, geotextiles and automobile seats. In contrast, the applications of this fiber in civil engineering are very few and do not commensurate with its potential. In the future, more research and investigation are needed to show coconut fiber as a possible reinforcement in the construction field.

The properties of natural fibers for their applications in civil engineering remain a topic of interest for a wide range of studies. Natural fibers are considered as the prospective material to be used as reinforcement materials in composite products. A detailed literature review on the properties of coconut fiber and its comparison with other natural fibers is reported in present study. Mechanical properties of vegetable fibers depend on factors such as their physical, chemical, morphological and 
geometrical characteristics. Munawar et al. [10] have investigated relationships between the density, diameter and mechanical properties of seven non-wood plant fiber bundles (including abaca leaf fiber, pineapple leaf fiber, sansevieria fiber, sisal fiber, coconut fiber, kenaf fiber and bast fiber). The results show that the density and mechanical properties of the fiber decreased with increasing fiber bundle diameter. In addition, only coconut fiber exhibits an almost circular shape on the cross-section, while the cross-sectional shape of other fibers varies widely. Sengupta et al. [11] analyzed the main physical properties of coconut fiber and indicated that there is a dissymmetrical nature with a big coefficient of variation in the distribution of length, diameter, density, breaking toughness and extension, specific work of rupture and flexural rigidity of untreated fibers. They recommended the usage of long fibers ( $25.4 \mathrm{~mm}$ or $1 \mathrm{inch}$ ) to manufacture the traditional ropes and coarse floor covering. Single or with other fibers, medium length fibers (12.7 $\mathrm{mm}$ or $\frac{1}{2}$ inch) will better suit to produce finer textile materials with improved characteristics. Contrarily, short fibers $(3.8 \mathrm{~mm}$ ) may be engaged in making not only flexible or semi-rigid composites but also geo-fiber for stabilization of soil. According to Tran et al. [12], the density of coconut fiber decreases from 1.3 to $0.9 \mathrm{~g} / \mathrm{cm}^{3}$ while the fiber porosity increases from $22 \%$ to $31 \%$ with the increase in the fiber length from 0.05 to $4.0 \mathrm{~mm}$. This phenomenon can be explained by considering the structural characteristic of coconut fiber. Enclosed porosity, which is included in the measured volume of solid material of coconut fiber, is increased with the increase in fiber length. This result shows that the length of fiber has direct effects on its density. The results from a number of studies $[10,12-17]$ confirm that coconut fiber is not very strong and stiff. However, its high strain to failure value may lead to an increase in the toughness of composites while using it as reinforcement for the composites.

Weak bonding between fibers and the matrix and their relatively significant moisture absorption are considered as the main drawbacks of natural fibers in composite products [18]. Thus, to modify the surface properties of fibers for improving their adhesion with the matrix, treatment of fibers is highly considered. Some techniques, including physical and chemical methods to treat fibers before using them in composites, are presented in several papers [15,19-21]. The researches related to the effects of treated fibers on the properties of fiber-reinforced composites are also available in different papers $[13,22-25]$. The influence of treatment methods on the physical and mechanical properties of coconut fibers were also reported in [20], which stated that softening treatment of raw fibers using a solution of $\mathrm{Na}_{2} \mathrm{~S}, \mathrm{Na}_{2} \mathrm{CO}_{3}$, and $\mathrm{NaOH}$ decreases the flexural rigidity value of raw fiber by three fourths without any degradation of desired characteristics.

In terms of thermal conductivity of plant fibers, some studies [2,26-29] introduced the potential use of plant fibers as thermal insulation materials in construction which can reduce environmental impacts in comparison with currently used synthetic thermal insulation materials. Manohar [26] reported that experimental thermal conductivities of coconut fibers at mean temperature $\left(15.6{ }^{\circ} \mathrm{C}\right)$ in accordance with ASTM C518 lie between 0.04869 and $0.05624 \mathrm{~W} / \mathrm{m} . \mathrm{K}$ for densities varying from 90 and $40 \mathrm{~kg} / \mathrm{m}^{3}$. Researchers then even suggested creating composites with two or more types of fibrous plants for thermal insulation materials. Khedari et al. [30] mixed durian peels and coconut fibers (ratio of 90:10 coconut fibers and durian peel by dry weight) to manufacture particleboards with low thermal conductivity (in the range of $0.054-0.1854 \mathrm{~W} / \mathrm{m} . \mathrm{K}$ ) depending on the board density. This result shows viable options to apply plant fibers in building insulation (wall and ceiling).

Regarding the durability of fiber, Sivakumar Babu et al. [31] reported that coconut fibers lasted only for 2-3 years without any treatment. Hejazi et al. [32] indicated that coconut fiber retained $80 \%$ of its tensile strength after six months of embedment in clay. Arifuzzaman Khan et al. [21] conducted a series of experiments indicating that all the treatments using sodium chlorite, sodium hydroxide, and acrylamide monomer could cause changes in the physical and chemical properties. These treatments improve the thermal stability of coconut fiber by causing lower weight loss and shifting of degradation peak to a higher temperature. When exposed to $180{ }^{\circ} \mathrm{C}$, within $5 \mathrm{~h}$, the drop of approximately $36.4 \%$, $24.6 \%$, and $23.2 \%$ in the tensile strength was observed for the fibers treated with sodium chloride, sodium hydroxide and acrylamide monomer chlorite, respectively. Thermogravimetric analysis (TGA) 
was performed to determine the weight loss of some fiber components, along with deterioration products [15]. From the TGA results, it can be seen that the residual mass of heat untreated coconut fibers is lower as compared to the treated coconut fibers in the temperature range of up to $900{ }^{\circ} \mathrm{C}$, which included the thermo-oxidative effect and evaporation of low molecular weight components in lignocellulose fibers. Hemicellulose is the most sensitive reactive constituent and its thermal degradation is easier than cellulose and lignin, according to Stevulova et al. [33].

These coconut fibers could play an important role in reinforcing the building materials or improving/modifying their certain properties. Mechanical, thermal and acoustic properties are highly dependent on the characteristics of the fiber itself. As reported by various authors in the literature, the determination of the characteristics of coconut fibers poses a problem due to the great variability of these. This variability depends on several factors, such as the origin of the coconuts and the storage and processing methods used to obtain these fibers. Each study, like that of the incorporation of coconut fibers in mortars, requires an appropriate determination of the properties of the fibers used, i.e., the potential deposit of fibers at its disposal. The present paper aims at providing further knowledge on the determination of coconut fibers properties in manufacturing reinforced mortars by incorporating different amounts of this type of fibers. The purpose of this present study is the assessment of geometrical, physical and mechanical to thermal properties and durability properties of local coconut fibers (Vietnam). Once determined, these properties are compared with those observed in the literature. This comparative study makes it possible to situate the level of performance of these fibers with respect to other natural fibers, in particular coconut fibers, and to consider using them as reinforcement in mortars. If the fibers tested are suitable for the manufacture of reinforced mortars, it seems necessary to control their preparation. This approach could, therefore, constitute an alternative solution to waste management and contribute to the development of reinforced mortars improving comfort performance in buildings.

\section{Material and Methods}

\subsection{Preparation of Fibers}

The fibers used in the present study were obtained from mature coconut husk extraction at Ben Tre province, Vietnam, one of the most famous places for growing coconut and for coconut products.

Without any treatment, these fibers are considered as raw or natural fibers. Two simple treatment methods for fibers are applied (i) boiling of fiber (ii) alkaline treatment of fiber, physical and eco-friendly treatment and chemical treatment, respectively.

The process of treatment is shown in Figure 1. The properties of untreated and treated fibers were evaluated and the resulting data were compared.

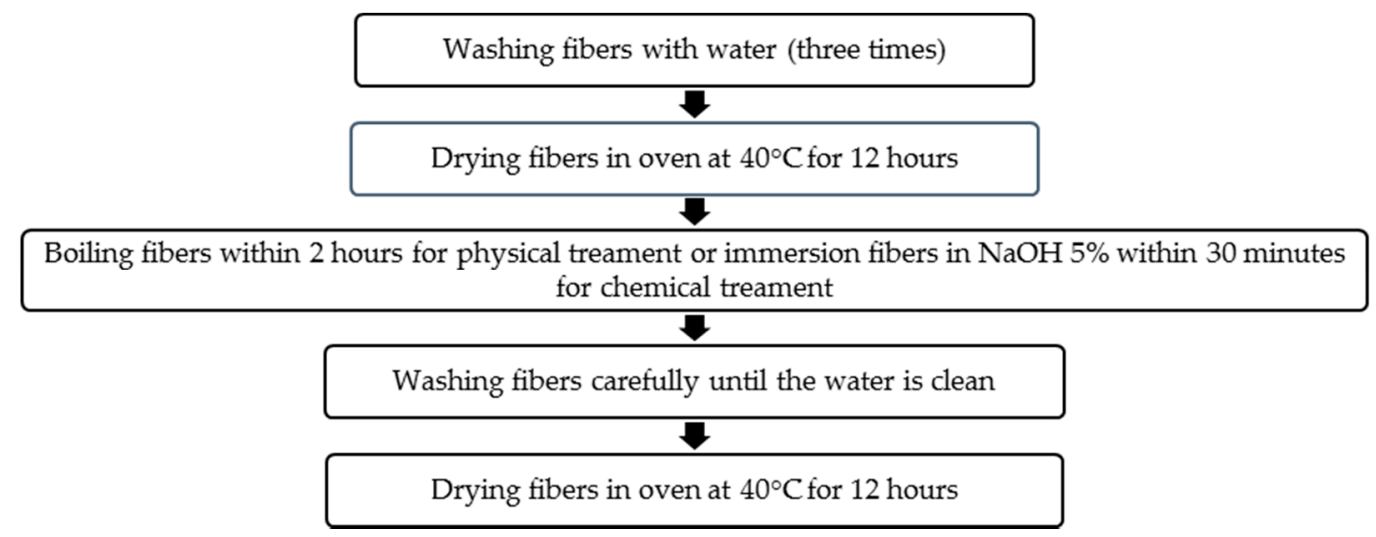

Figure 1. Process of fiber treatment applied. 


\subsection{Testing Methods for the Determination of Fiber Properties}

\subsubsection{Microscope Image}

The coconut fiber's microstructure was examined using the digital microscope model Keyence VHX 6000 (Keyence France SAS, Bois-Colombes, France). The microscope is operated under the power voltage of $240 \mathrm{VAC}$ and frequency of $60 \mathrm{~Hz}$. This device combines observation of captured images and measurement functions while providing a screen interface that makes visualization easier. Hence, the digital microscope made it possible to observe cross-section and external surface of coconut fibers.

\subsubsection{Absolute Density}

Besides the mechanical properties, the density of the fiber is a crucial parameter to determine the fiber's potential for lightweight material when using as reinforcement in a composite [18]. The determination of the absolute density of the fibers was conducted using a helium pycnometer, namely AccuPyc II 1340 (Micromeritics France SA, Verneuil-en-Halatte, France). Ten samples were tested for each kind of fiber (mass of fiber $0.5 \mathrm{~g} /$ test at ambient conditions). Volume was then measured by means of the pycnometer at the same temperature. The final density was the average of the ten values.

\subsubsection{Water Absorption}

Natural fibers are hydrophilic materials that absorb water used for manufacturing elements or composites [34]. For the water absorption test of fiber, the recommendation of RILEM TC 236-BBM (RILEM Association, Paris, France) [35] was used as a protocol of this test. The measurement of water absorption is based on the difference in the mass of dry fibers and fibers undergoing immersion at different times. Initially, a bundle of fibers weighing $2 \mathrm{~g}$ was placed in a ventilated oven at $60{ }^{\circ} \mathrm{C}$ until the change in mass of the sample is less than $0.1 \%$ within $24 \mathrm{~h}$. The fiber bundles were placed in a permeable bag that was then immersed in distilled water to reach its absorption. After the immersion time of 1, 15, 240 and $2280 \mathrm{~min}$, a centrifuge having speed of $500 \mathrm{rpm}$ was used for $30 \mathrm{~s}$ to remove the excess water from these fiber bundles. Absorption capacity was calculated by using the following equation:

$$
\text { water absorption }=\frac{\text { impregnated mass }- \text { dry mass }}{\text { dry mass }} \times 100 \%
$$

\subsubsection{Thermal Conductivity}

Thermal conductivity $\lambda$, defined by the steady-state heat flow moving through a unit area of a homogeneous material, $1 \mathrm{~m}$ thick, induced by a $1 \mathrm{~K}$ difference of temperature on its faces, is one of the most interesting characteristics for thermal insulation materials [36]. According to ASTM C518, the thermal conductivity of coconut fiber was measured by using heat flow meters (HFM 436 Lambda, from NETZSCH-Gerätebau GmbH, Selb, Germany) kept at $20.5^{\circ} \mathrm{C}$, as shown in Figure 2. A polystyrene frame with a very thin bottom face contains the fibers (see Figure 3). The thermal conductivity tests were carried out at a mean temperature of $30^{\circ} \mathrm{C}$ with the density of specimens varying from 30 to $120 \mathrm{~kg} / \mathrm{m}^{3}$ by an increment of $10 \mathrm{~kg} / \mathrm{m}^{3}$. 

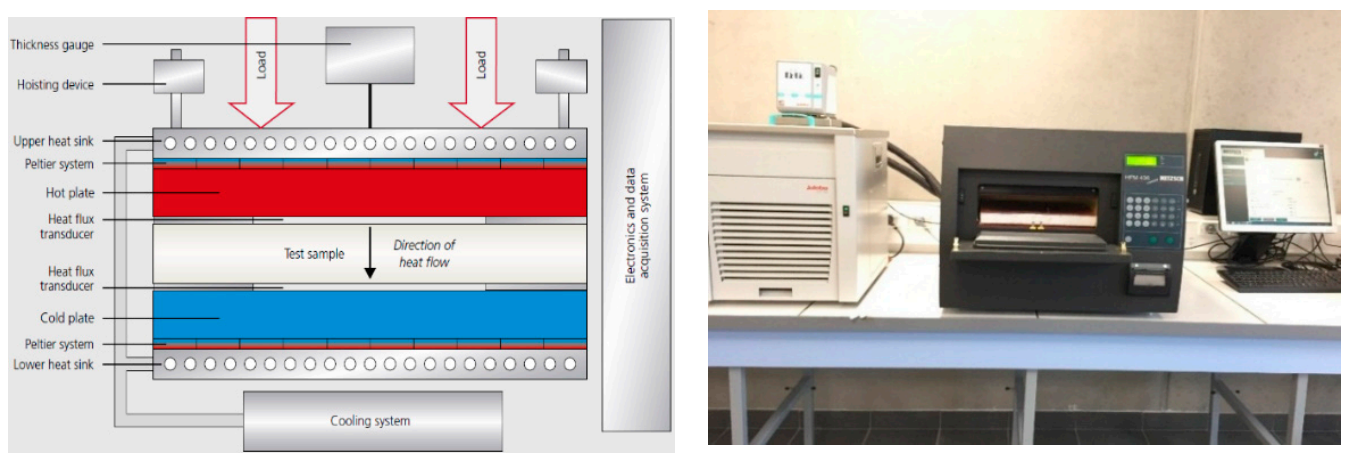

Figure 2. Test device for thermal conductivity, (Heat Flow Meter -HFM 436 Lambda).
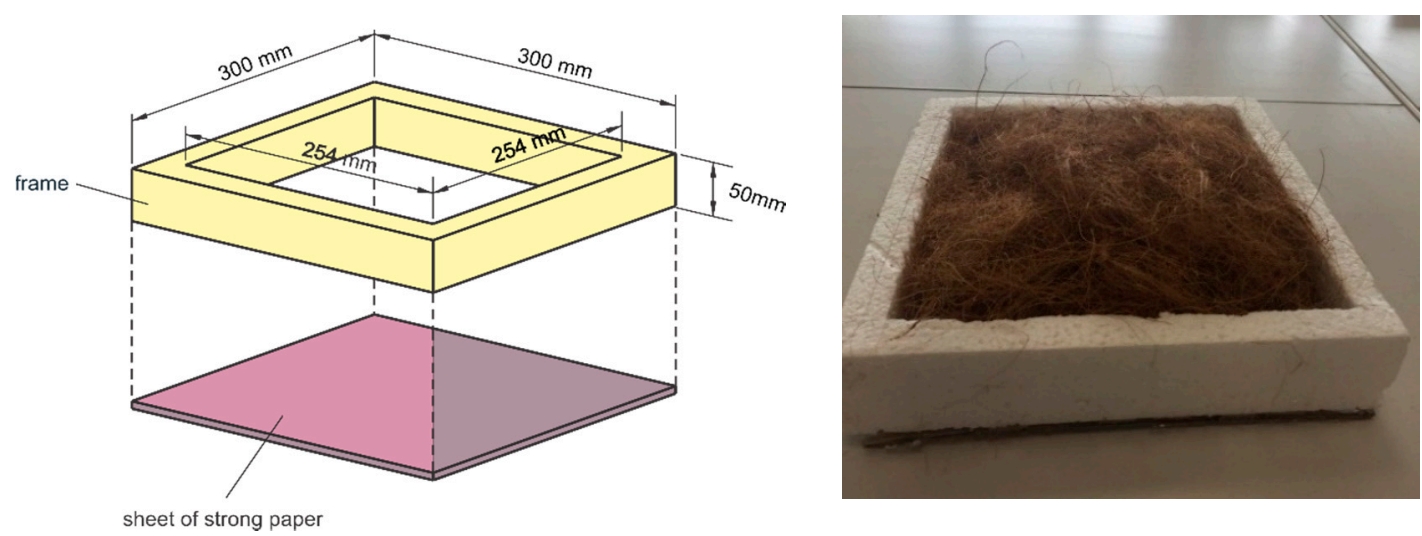

Figure 3. Specimen holder.

\subsubsection{Direct Tensile Test}

The single fiber tensile test was conducted using an INSTRON 3369 universal testing machine (INSTRON ${ }^{\circledR}, 825$ University Ave Norwood, Norwood, MA 02062-2643, USA), as shown in Figure 4, in accordance with ASTM C1557. In order to prepare specimens for the test, transparency paper frames having dimension $4 \mathrm{~cm} \times 4 \mathrm{~cm}$ were used to fix fiber in the middle by means of adhesive tape and cut both sides of them very carefully at mid-gauge before the test as shown in Figure 5. The fiber was tested with a free length of $2 \mathrm{~cm}$ using the displacement control at a rate of $0.5 \mathrm{~mm} / \mathrm{min}$ and two clamps having a $10 \mathrm{~N}$ maximum load. Finally, 16 specimens were performed for each type of fiber. Extreme values were removed and replaced by other specimens tested.

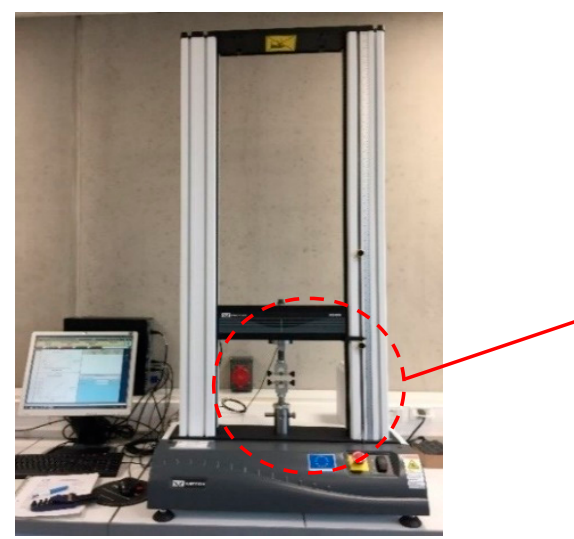

(a)

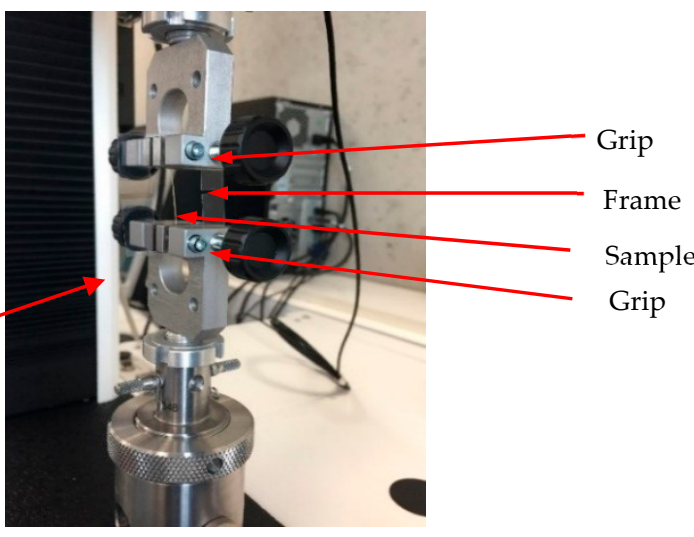

(b)

Figure 4. Setup of the tensile test according to ASTM C1557: (a) INSTRON 3369 universal testing machine; (b) details of grips and specimen. 


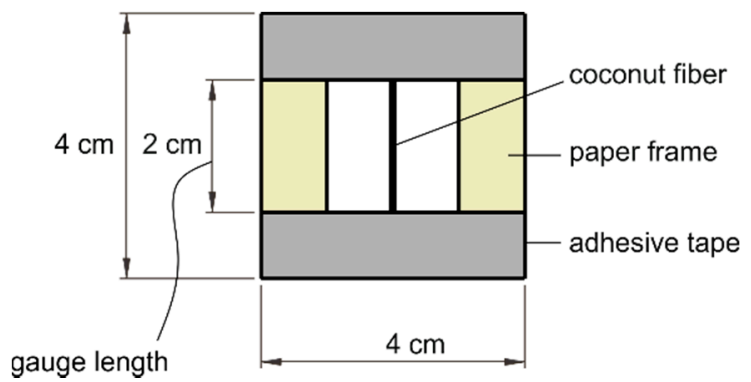

(a)

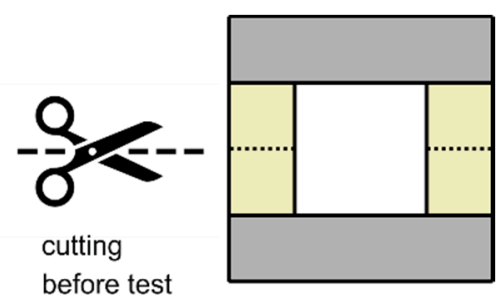

(b)

Figure 5. Single fiber specimen before direct tensile test: (a) transparency paper frame for fixing fiber; (b) cutting of the frame before fiber testing.

The ultimate tensile strength of the fiber is calculated as follows:

$$
\sigma=\frac{F_{\max }}{A}
$$

where $\sigma$ is the ultimate tensile strength in $\mathrm{MPa}, F_{\max }$ is the maximum force at failure in $\mathrm{N}$, and $A$ is the fiber cross-section area at fracture plane in $\mathrm{mm}^{2}$.

In order to measure the cross-section of each fiber after the tensile test, a borderline is drawn to define the cross-section area of fiber, and then the surface area is determined as illustrated in Figure 6.

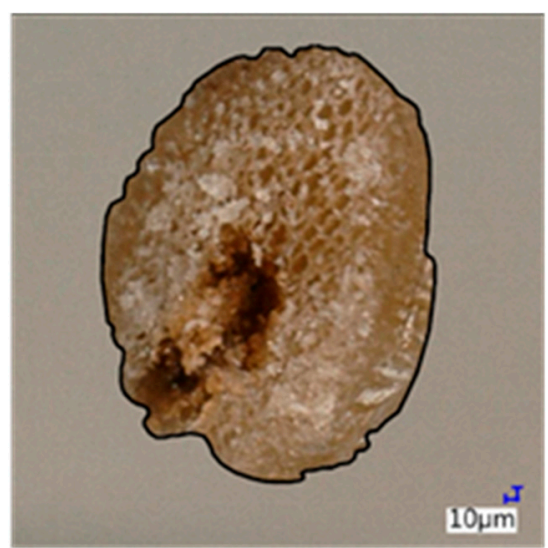

Figure 6. Area calculation.

The tensile strain of fiber is calculated as follows:

$$
\varepsilon=\frac{\Delta l}{l} \times 100
$$

where $\Delta l$ is the elongation of the gauge length in $\mathrm{m}$ and $l$ is the initial gauge length, $20 \mathrm{~mm}$.

\subsection{Durability}

The durability of fibers was taken into account not only during the preparation of composites but also during their period of application [18]. In present study, two types of durability were considered: thermal and chemical stability.

\subsubsection{Thermal Stability}

Thermal analysis provides additional benefits to understand the degradation mechanism and the enhancement of the thermal stability of material [33]. Thermal gravimetric analysis (TGA) and 
differential thermal analysis (DTA) diagrams of fiber with and without treatment were conducted on the STA 449 F5 Jupiter Simultaneous Thermal Analyzer device under nitrogen atmosphere. A starting temperature of $25^{\circ} \mathrm{C}$ was used with a heating rate of $20^{\circ} \mathrm{C}$ per minute and a final temperature of $900^{\circ} \mathrm{C}$.

For the preparation of the test, fibers were cut into small pieces of $0.5 \mathrm{~mm}$ in length. The mass of each sample ranged from 10 to $15 \mathrm{mg}$ and was placed into the platinum crucible.

\subsubsection{Chemical Stability}

The most suitable test method for chemical stability is to expose the fibers to chemicals [37]. After the exposure, the degradation of the fiber could be tested by determining the change in the mass of the fiber.

Cementitious composite gives an alkaline environment due to the production of calcium hydroxide by the hydration of Portland cement. Also, the typical deterioration of cementitious composite happens under the attack of chloride and sulphate ions from the salt water, de-icing salts, soil and groundwater [38]. In the present study, in order to determine the chemical stability of coconut fiber, sodium hydroxide $\mathrm{NaOH} 10 \%$ and calcium hydroxide $\mathrm{Ca}(\mathrm{OH})_{2}$ saturated solution were prepared. The procedure of the exposure of fiber is given in Figure 7.

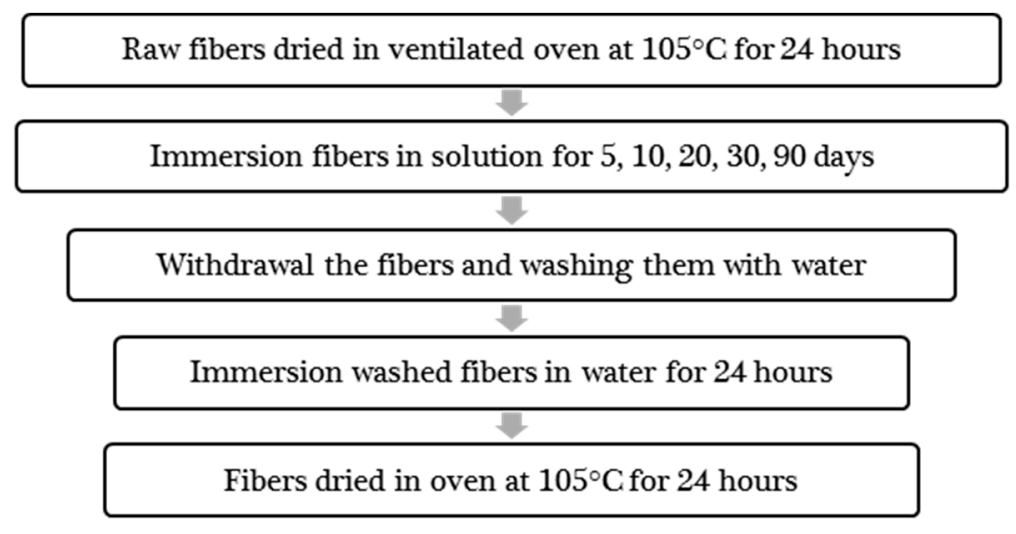

Figure 7. The exposure procedure.

The retention of mass was calculated by the following equation:

$$
\text { Mass retention } \%=\left(1-\frac{\text { initial mass }- \text { mass after immersion }}{\text { initial mass }}\right) \times 100 \%
$$

\section{Results and Discussion}

\subsection{Geometrical Properties}

Figure 8 shows the surface and cross-section of coconut fibers tested using the digital microscope. As illustrated, the diameter of fiber was decreased by approximately $10 \%$ and $30 \%$ due to alkali and boiled treatment methods, respectively. In addition, the images depict that the process of treatment of fibers causes morphological changes with an increase in voids and a rougher surface because of the removal of most of the pectin, ash and other impurities. Most fibers do not have a circular cross-section, so a heterogeneous distribution of loading occurs that makes predicting the mechanical properties of fibers, as well as composites incorporating fibers, become difficult. 

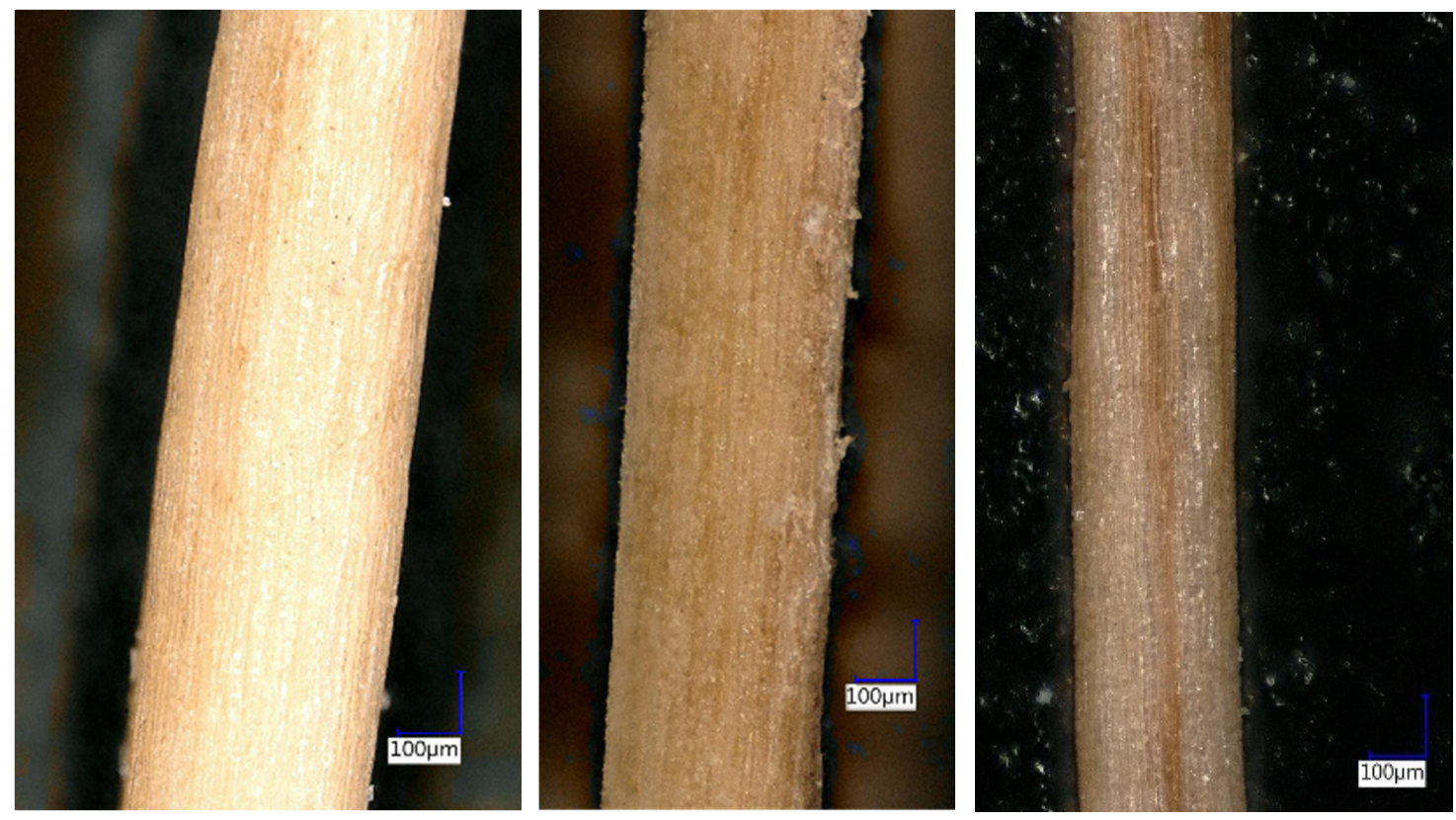

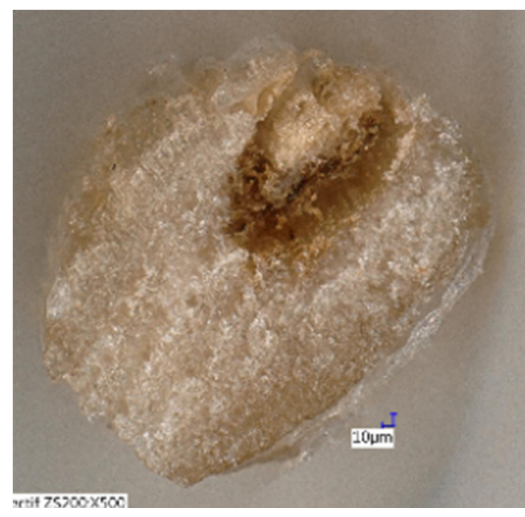

(a)

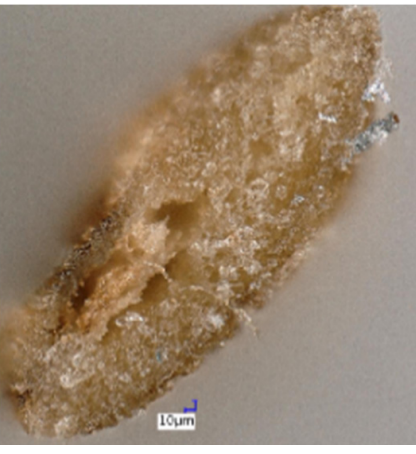

(b)

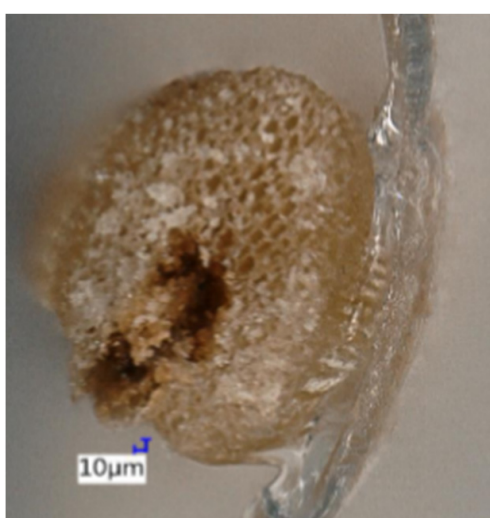

(c)

Figure 8. Microscope images of surface and cross-section of fiber: (a) raw fiber (RF); (b) alkali-treated fiber (ATF); (c) boiled fiber.

A survey of the diameter of three hundred raw fibers by means of image analysis method indicates that average diameter in two directions at right angle ranges from 0.090 to $0.39 \mathrm{~mm}$. Diameters ranged from 0.20 to $0.35 \mathrm{~mm}$ represent about $70 \%$ of the total, as shown in Figure 9. In comparison with previous studies, raw coconut fiber in the present study was found to be smaller in diameter than the raw fibers from Mexico $(0.51 \mathrm{~mm})$ [39], Taiwan $(0.43 \mathrm{~mm})$ [40] or Malaysia $(0.32 \mathrm{~mm})$ [14]. 


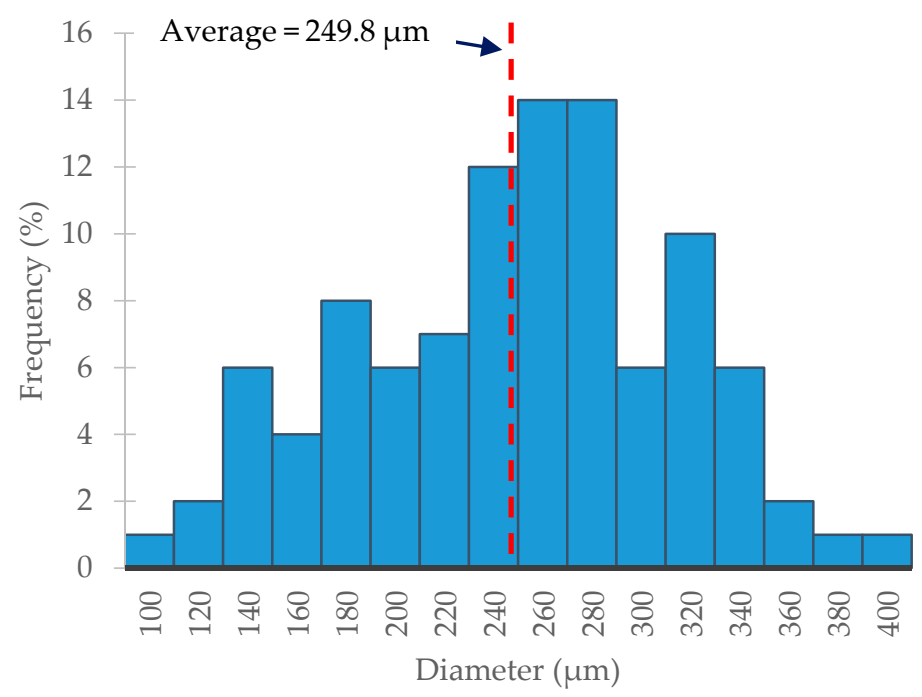

Figure 9. Diameter distribution of raw coconut fibers.

\subsection{Physical Properties}

Experimentally, the absolute density of the coconut fibers tested in the present study is reported in Table 1. This result is in line with the observations already made in [13,41-43]. This value is less in comparison with commonly used fibers like steel fiber $\left(7.80 \mathrm{~g} / \mathrm{cm}^{3}\right)$, carbon fiber $\left(1.75 \mathrm{~g} / \mathrm{cm}^{3}\right)$ [44], or glass fiber $\left(2.55 \mathrm{~g} / \mathrm{cm}^{3}\right)$ [45]. This is the reason behind the suggestion of coconut fiber being used in the production of the structural lightweight composite [46,47].

Table 1. Absolute density of fiber.

\begin{tabular}{ccc}
\hline Fiber & Average Value $\left(\mathrm{g} / \mathrm{cm}^{3}\right)$ & Standard Deviation $\left(\mathrm{g} / \mathrm{cm}^{3}\right)$ \\
\hline Raw fiber (RF) & 1.41 & 0.0014 \\
Alkali-treated fiber (ATF) & 1.51 & 0.0014 \\
Boiled fiber (BF) & 1.50 & 0.0010 \\
\hline
\end{tabular}

No significant difference is observed between the absolute density of alkali-treated fibers and boiled fibers, but the absolute density of raw fibers is lower than that of treated ones. The absolute density of the fibers is significantly increased when treated with alkali or by the boiling method. Treatment dissolves pectin and impurities, due to which the volume is reduced and a gain in absolute density is observed. According to some researches [2,48], the content of ash in fibers has been reduced by approximately $70 \%$ after treatment.

Graphs of water absorption versus time are presented in Figure 10. Both of two applied treatments led to a decrease in the absorption capacity of coconut fibers. As shown in Figure 10, the fibers absorb water rapidly in the initial step until a saturation level is achieved. The water absorption of fibers reaches rapidly about $100 \%$ for raw fibers and alkali-treated fibers and approximately $35 \%$ for boiled fibers within a short amount of time. However, from the four-hour immersion, these curves rise gradually to reach a constant value at the end of the process. From these observations, the water absorption of fibers is considered as sufficiently stable at $48 \mathrm{~h}$ and the values obtained are $133 \%, 130 \%$, and $50 \%$ for raw, alkali-treated and boiled fibers, respectively. Fibers become fully saturated after the two-day-immersion period. 


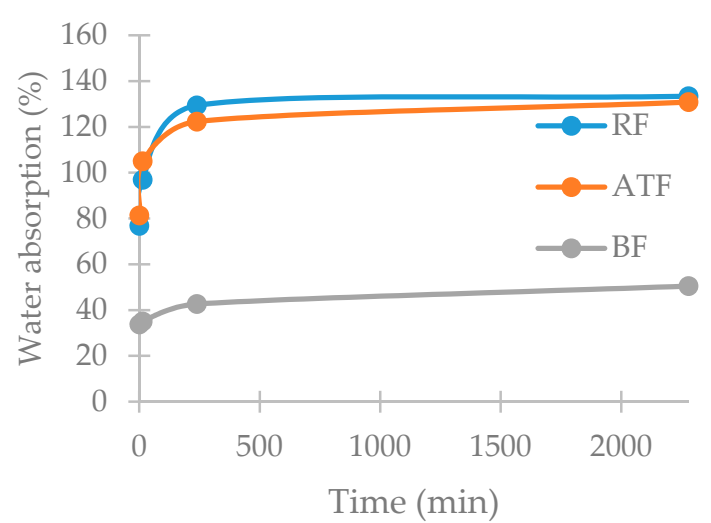

(a)

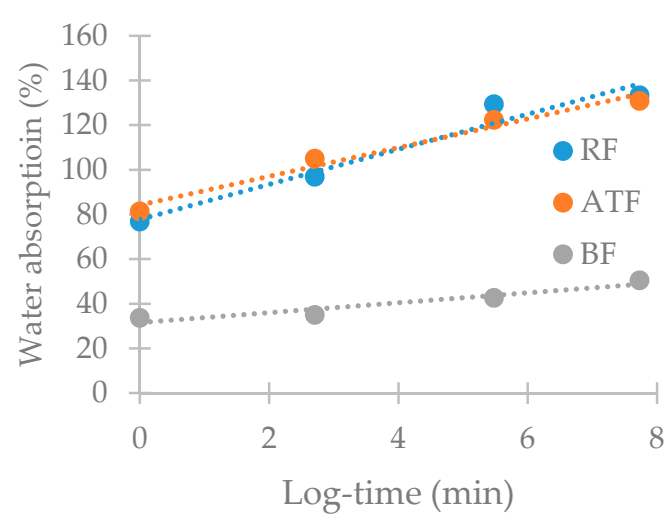

(b)

Figure 10. Water absorption of coconut fibers: (a) versus time; (b) logarithmic scale.

Considering the observation time, the water absorption of coconut fibers resembles a logarithmic law as follows:

$$
\mathrm{W}(\mathrm{t})=\mathrm{K}_{1} \times \log (\mathrm{t})+\mathrm{IRA}
$$

where IRA is the initial rate of the absorption (after an immersion of $1 \mathrm{~min}$ ) and $\mathrm{K}_{1}$ corresponds to the slope of the function $\mathrm{W}(\mathrm{t})$ exposed in logarithmic time. These values are listed in Table 2.

Table 2. Data results from water absorption test in logarithmic law.

\begin{tabular}{ccc}
\hline Type of Fiber & Initial Rate of Absorption IRA in \% & The Slope of the Curve $\mathbf{K}_{\mathbf{1}}$ \\
\hline RF & 77.82 & 7.86 \\
ATF & 84.28 & 6.42 \\
BF & 31.67 & 2.21 \\
\hline
\end{tabular}

One of the main reasons behind the change in absorption capacity of the fiber is hemicelluloses. Another reason is the critical role of crystalline cellulose and lignin in the water absorption process. Moisture causes the cell wall of lignocellulose fiber to swell until it reaches its saturation [49].

The water absorption of boiled fibers was observed to be half that of the raw and alkali-treated fibers. It seems that alkaline treatment was less effective on the absorption capacity of fiber than physical treatment. In addition, the alkali-treated fiber structure was observed to be denser after treatment. The reduction in the absorption capacity of boiled fiber could be explained according to Ferreira et al. [49]. After several wetting and drying cycles, boiling with the addition of water during the boiling process, packing and a tightening of the fiber cell are increased. In addition, the lumen is decreased due to the treatment process, which results in a reduction in the fiber's water absorption capacity. From the observation of cross-section of the coconut fiber (see Figure 8c) there is a lumen in the middle and irregular multi-voids around, which indicates its higher water absorption than some others.

Pretreatments could result in a surface morphology modification (such as surface geometry, surface roughness, dirt removal) and microstructure change from pores to macro pores [50]. Rawangkul et al. [51] observed a reduction in the volume of the void by using Mercury Intrusion Porosimetry (MIP) measurements on boiled coconut fibers. The total volume of mercury intruding up to the maximum pressure was 4.16 and $2.52 \mathrm{~cm}^{3} / \mathrm{g}$ for $0.5 \mathrm{~h}$ boiled fiber and $1 \mathrm{~h}$ boiled fiber, respectively. At the same time, they observed a reduction in the surface areas. The surface area of $0.5 \mathrm{~h}$ boiled fiber was higher than that of $1 \mathrm{~h}$ boiled coir. In addition, the reduction in porosity can be qualitatively observed by images given in Figure 8. 
Table 3 recaps the water absorption capacity of some plant fibers. The capacity of fiber to absorb water diminishes the durability of fiber-reinforced composites. Water absorption results in volume changes that can lead to the appearance of cracks in composites [52]. The water absorption capacity is a crucial drawback of plant fibers for their application in construction materials. Limiting water absorption is thus often desirable to enhance the durability of composites. Coating fibers to avoid water absorption and alkaline environment was suggested by Pacheco-Torgal et al. [52] as a valuable way to upgrade the durability of fiber-reinforced concrete.

Table 3. Water absorption capacity of some plant fibers from the literature.

\begin{tabular}{ccc}
\hline Reference & Type of Fiber & Water Absorption in \% \\
\hline$[29]$ & Oil palm & 54 \\
{$[53]$} & Flax & 132 \\
Present study & Coconut & 133 \\
{$[54]$} & Bamboo & 145 \\
{$[29]$} & Bagasse & 153 \\
{$[49]$} & Sisal & 180 \\
{$[55]$} & Kenaf & 307 \\
{$[56]$} & Corn cob & 327 \\
\hline
\end{tabular}

\subsection{Thermal Conductivity}

The thermal conductivities of fibers tested are given in Figure 11. It is clear from the figure that there is no significant difference in thermal conductivities for the three kinds of fibers considered. That means the treatment processes do not influence the thermal conductivity of fiber. The thermal conductivities of fibers decreased from nearly 0.052 to approximately $0.024 \mathrm{~W} / \mathrm{m} . \mathrm{K}$ with the increase in density from 30 to $120 \mathrm{~kg} / \mathrm{m}^{3}$. Conductivities observed for each type of fiber are smaller than $0.1 \mathrm{~W} / \mathrm{m} . \mathrm{K}$, and according to Asdrubali et al. [57], materials with a thermal conductivity lower than $0.1 \mathrm{~W} / \mathrm{m} . \mathrm{K}$ are considered as thermal insulators. Thus, coconut fiber is an excellent candidate for building insulation materials.

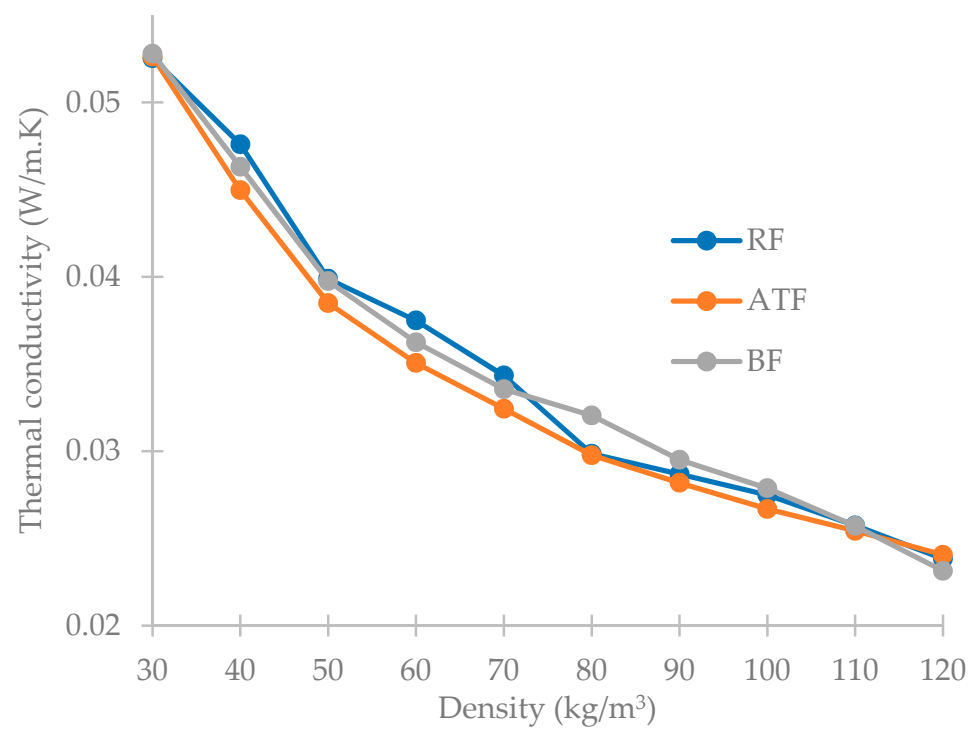

Figure 11. Relationship between thermal conductivity and density of coconut fibers.

Thermal conductivity depends on the component of fibers, as indicated in the study by Guillou et al. [58]. Based on three main constituents of natural fibers (cellulose, hemicellulose and lignin), they developed a model to predict the thermal conductivity of individual material with the value 
of 0.291 and $0.2668 \mathrm{~W} / \mathrm{m} . \mathrm{K}$ for individual kenaf and hemp fiber, respectively. Also, thew heterogeneities of the natural fibers induce difficulty in the measurement of the fibers' thermal properties.

\subsection{Mechanical Properties}

Tensile strengths and tensile strains of single raw and treated fibers are given in Table 4 . The results indicate that the physical treatment decreased the tensile strength by approximately $17 \%$, while the chemical treatment decreased the tensile strength by $11 \%$ in comparison with raw fiber. It is evident that the tensile strength of coconut fibers was deteriorated with boiled and alkali treatments. Raw fiber is stronger and less brittle as compared to treated coconut fiber. A similar downward trend was also observed when $\mathrm{Gu}$ [59] treated coconut fibers with the $\mathrm{NaOH}$ solution. The chemical treatment and several wetting cycles in physical treatment provide more $\mathrm{Na}+$ and $\mathrm{OH}$ - ions. These ions react with the cellulose in the fiber. In addition, the several wetting cycles in the physical treatment method result in the partial removal of lignin, pectin, and fatty acid, which is the detrimental factor to the fiber strength. The cellulose in natural fiber is mainly responsible for the mechanical properties of the fiber [60]. In order to compensate for the loss of strength of fibers, the use of resin can improve the strength of composite-incorporating fibers [61].

Table 4. Tensile strengths and tensile strains of coconut fibers.

\begin{tabular}{ccc}
\hline Type of Fiber & Tensile Strength at Failure (MPa) & Tensile Strain at Failure (\%) \\
\hline RF & $123.6 \pm 37.6$ & $26.9 \pm 9.9$ \\
ATF & $111.2 \pm 16.3$ & $31.8 \pm 10.6$ \\
BF & $105.9 \pm 10.3$ & $40.7 \pm 11.7$ \\
\hline
\end{tabular}

In contrast, an increase of $18 \%$ and $51 \%$ in the tensile strain at the failure was observed for chemically and physically treated fibers, respectively. The treated fibers became ductile because of the removal of the impurities [59].

Compared with other natural fibers, the coconut fiber has a significantly higher strain at failure. Table 5 shows the tensile properties of different raw fibers in the present study and others in previous works.

Table 5. Tensile properties of some plant fibers.

\begin{tabular}{cccc}
\hline Reference & Type of Fiber & Tensile Strength at Failure (MPa) & Tensile Strain (\%) \\
\hline Present study & Coconut fiber & $123.6 \pm 37.6$ & $26.9 \pm 9.9$ \\
[62] & Jute fiber & $393.0-773.0$ & $1.1-1.5$ \\
[63] & Sisal fiber & $530.0-640.0$ & $3.0-7.0$ \\
[53] & Flax fiber & $1254.0 \pm 456.0$ & \pm 0.6 \\
\hline
\end{tabular}

\subsection{Thermogravimetric Analysis}

Thermogravimetric analysis (TGA) and differential thermal analysis (DTA) diagrams are presented in Figure 12 and the results are summarized in Table 6.

It can be seen that the thermal behavior of coconut fiber is similar to that of other plant fibers, such as sisal $[64,65]$ or hemp [33]. Nearly the same trends were found among the pyrolysis behavior of the three types of fibers.

There are four main stages of mass loss in the pyrolysis process. The first stage is in the temperature range between ambient temperature and $140{ }^{\circ} \mathrm{C}$. The fibers start their decomposition easily with the mass loss of approximately $8 \%$ for treated fibers and $12 \%$ for fibers without treatment. This loss of mass would correspond mainly to the dehydration of the fiber whose water content is approximately $7-10 \%$ and the removal of volatile compounds. 


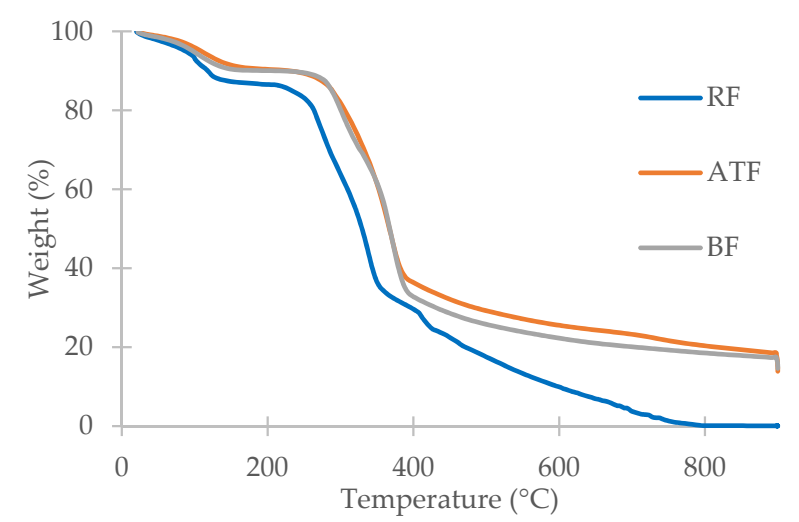

(a)

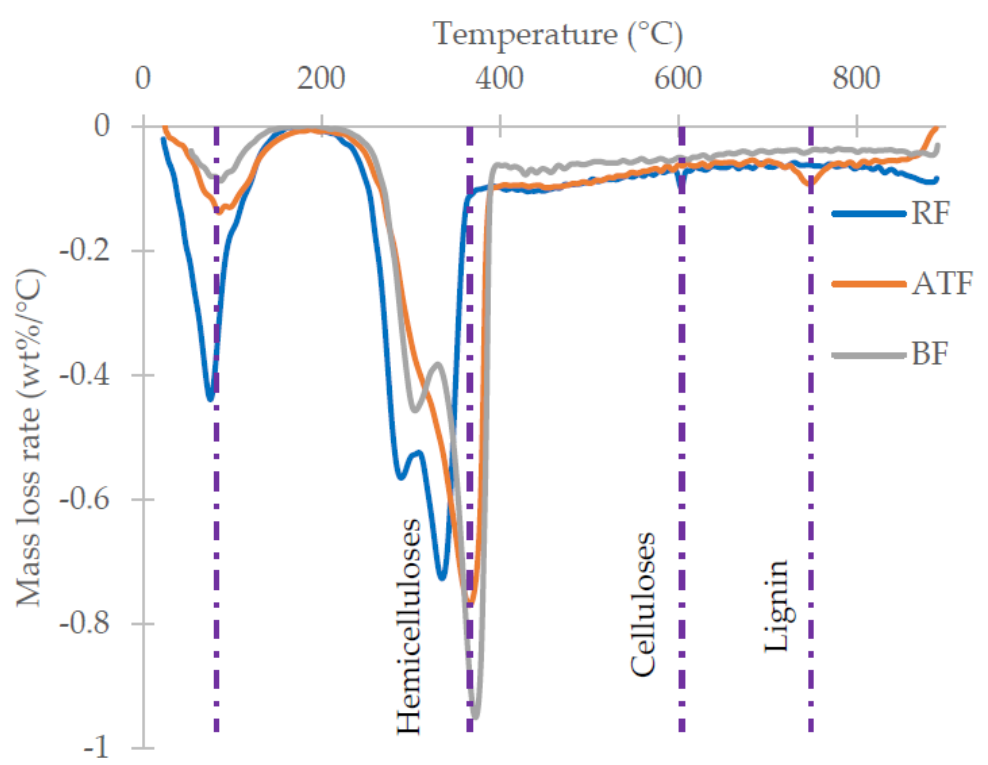

(b)

Figure 12. Thermal gravimetric of fibers tested: (a) thermogravimetric analysis (TGA); (b) differential thermal analysis (DTA).

Table 6. Thermal gravimetric data results of coconut fibers.

\begin{tabular}{cccc}
\hline Type of Fiber & $\begin{array}{c}\text { Transition Temperature } \\
\text { Range }\left({ }^{\circ} \mathbf{C}\right)\end{array}$ & Mass Loss (\%) & Residue Left at $\mathbf{9 0 0}{ }^{\circ} \mathbf{C}(\%)$ \\
\hline \multirow{3}{*}{ RF } & $20-140$ & 12.39 & \\
& $140-390$ & 44.40 & 0.05 \\
& $390-600$ & 33.31 & \\
$600-900$ & 9.85 & \\
& $20-140$ & 8.02 & \\
ATF & $140-390$ & 46.16 & \\
& $390-600$ & 20.28 & \\
& $600-900$ & 11.60 & \\
& $20-140$ & 9.37 & \\
\hline
\end{tabular}


The second stage of mass loss corresponds to hemicellulose degradation and occurs at $140{ }^{\circ} \mathrm{C}$. This phenomenon can be explained by the fact that hemicellulose contains a series of saccharides like xylose, mannose, glucose, and galactose, which are very easy to remove and deteriorate to volatiles evolving at low temperatures [66].

The next stage, which happens between 250 and $400{ }^{\circ} \mathrm{C}$, corresponds to cellulose degradation. Due to the firm and good order structure, the thermal stability of cellulose is higher.

Lignin is full of aromatic rings with various branches, which leads to its degradation occurring at last and ends at $900{ }^{\circ} \mathrm{C}$. At $900{ }^{\circ} \mathrm{C}$, the residual masses for raw, alkali-treated, and boiled fiber, are $0.05 \%, 13.94 \%$, and $14.64 \%$, respectively. It can be concluded that the treatment application has a significant effect on the thermal degradation behavior of coconut fibers. For natural coconut fiber, there is a temperature range between 150 and $615^{\circ} \mathrm{C}$, where the loss is the most significant (from $10 \%$ to $90 \%$ ). In comparison, thermal diagrams of treated fibers have a higher temperature range than that of raw fibers. Among the three types of fiber, alkali-treated fibers are the most difficult ones to decompose even if the boiled fibers behave similarly. Its decomposition happens slowly under the whole temperature range, i.e., from ambient temperature to $900^{\circ} \mathrm{C}$. For both types of treated fiber, the mass loss rates are the highest, at about $350-400{ }^{\circ} \mathrm{C}$, where the rate of boiled fiber peaks at $0.95 \mathrm{wt} \% /{ }^{\circ} \mathrm{C}$ and that of alkali-treated and raw fiber are maximum at $0.75 \mathrm{wt} \% /{ }^{\circ} \mathrm{C}$. From the temperature of $400{ }^{\circ} \mathrm{C}$, the degradation process of three types of fiber continues slowly and gets a stable value at around $0.1 \mathrm{wt} \% /{ }^{\circ} \mathrm{C}$. The small mass loss of cellulose and lignin under temperature development could be correlated with a reduction in water absorption capacity of the treated fibers as well as an increase in chemical stability that makes them less hydrophilic.

\subsection{Chemical Durability}

Figure 13 shows the mass retention of fibers immersed in different solutions. From the histograms, the calcium hydroxide solution indicates a lower mass loss than the sodium hydroxide solution. While the maximum weight loss is observed as approximately $37 \%$ for raw fiber in sodium hydroxide solution after the immersion time of 90 days, this number is only around $25 \%$ for both other types. This could be due to the presence of numerous pores, which allows the aqueous solution to permeate into and break down the silicon linkage [38]. On the other hand, by virtue of the process of treatment, the chemical degradation of the treated fiber is slower than that of the fiber without treatment. The retentiveness of the mass of the fiber with treatment in sodium hydroxide solution $\mathrm{NaOH}$ at the end of 90 days is approximately $75 \%$ in comparison to $63 \%$ for the raw fiber in the same immersion situation. Similarly, the weight of the raw fiber decreases by $20 \%$ at the end of the calcium hydroxide solution $\mathrm{Ca}(\mathrm{OH})_{2}$ immersion period. On the other hand, those of the treated fibers decrease only by $12 \%$. This happens because pectin, ash and other impurities, which are easier to degrade than three main components of fiber, had been removed due to the treatment process.

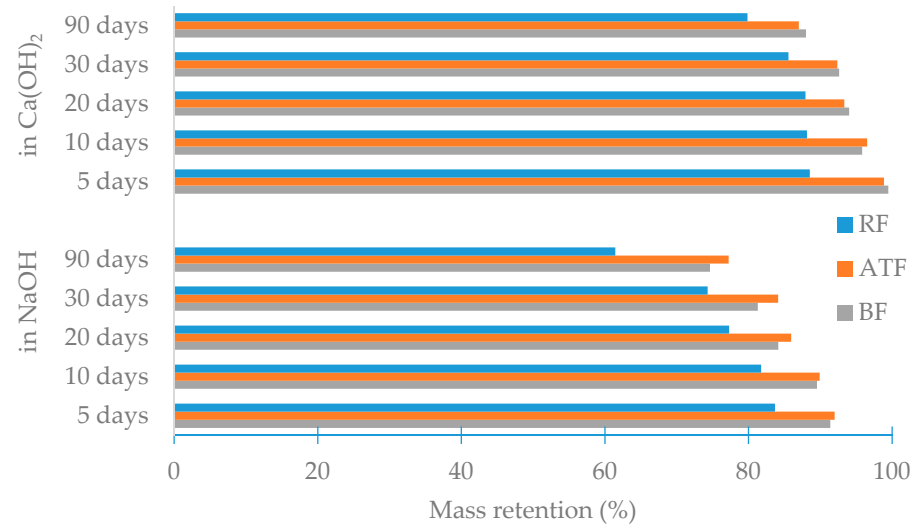

Figure 13. Change of fiber mass in sodium solution or calcium hydroxide solution. 


\section{Conclusions}

The knowledge of the properties of coconut fiber is necessarily required to use it as reinforcement in composite materials. Two treatment approaches were considered: physical and chemical methods. The experimental results obtained put forward the following conclusion:

The treatment process removes a part of the fiber surface, resulting in a rougher fiber surface and increased absolute density as well as the decreased diameter of fiber by roughly $10 \%$ and $30 \%$ for alkaline and boiled treatment, respectively.

Water absorption capacities of alkali-treated and raw fiber were found to be almost the same, but there was a remarkable reduction in water absorption capacity of boiled fiber.

The experiments to determine the thermal conductivity of the bundles of fiber have shown that both treatment methods do not affect the thermal conductivity values. For all types of fiber, the thermal conductivity was decreased from 0.052 to $0.024 \mathrm{~W} / \mathrm{m} . \mathrm{K}$ with the increase in density of the fiber bundles from 30 to $120 \mathrm{~kg} / \mathrm{m}^{3}$.

Both treatment processes decreased the tensile strength of the fiber. This happens due to a reduction in lignin, pectin, fatty acid and cellulose due to the treatment process. By contrast, tensile strains at failure of fibers were increased significantly by $18 \%$ and $51 \%$ after chemical and physical treatment, respectively. This implies that the ductility of fibers has increased after treatment.

The same trend of thermal behavior of all the types of fibers was found in TGA and DTA tests. However, the higher thermal stability of treated fibers was observed in comparison to raw fiber by virtue of the partial removal of impurities. The residue of treated fibers left at $900{ }^{\circ} \mathrm{C}$ is higher than that of raw fibers.

Similarly, higher chemical durability with the application of both treatments was explained by exposing the fibers to the saturated solution of sodium hydroxide $\mathrm{NaOH}(10 \%)$ and calcium hydroxide $\left(\mathrm{Ca}(\mathrm{OH})_{2}\right)$. The results indicate that the mass loss of raw fiber is $37 \%$ and $20 \%$ in sodium and calcium hydroxide solution, respectively. Mass loss of treated fibers is roughly half as compared to raw fibers. The higher percentage of hemicellulose, cellulose, and lignin in treated fibers is the reason for this chemical durability.

A careful selection of fibers is a crucial task and required before using coconut fibers as well as other natural fibers in reinforced composites. Different parameters need to be identified, such as the origin and local and seasonal quality variations of the fibers in order to control the retting process, defects, and homogenous batches of fiber.

Considering the circular economy, sustainable development and environmental aspects, a simple method for coconut fibers preparation should be proposed, as illustrated in Figure 14. In the fiber preparation process, the collection must be installed near the coconut fields or the coconut pulp industry where raw coconut envelopes are collected. Husk retting and fibers extraction are processed using water without chemical additives at the same place. The water used is filtered and impurities gathered for biomass. Water is again reused for the retting process. Fibers are sun-dried and cut to the desired lengths with a knife mill machine equipped with various sieve sizes. In this cutting operation, coarse grains as chips are mixed with fibers that will be separated by means of an air jigging system. Finally, fibers cut to length are bagged like coconut chips. 


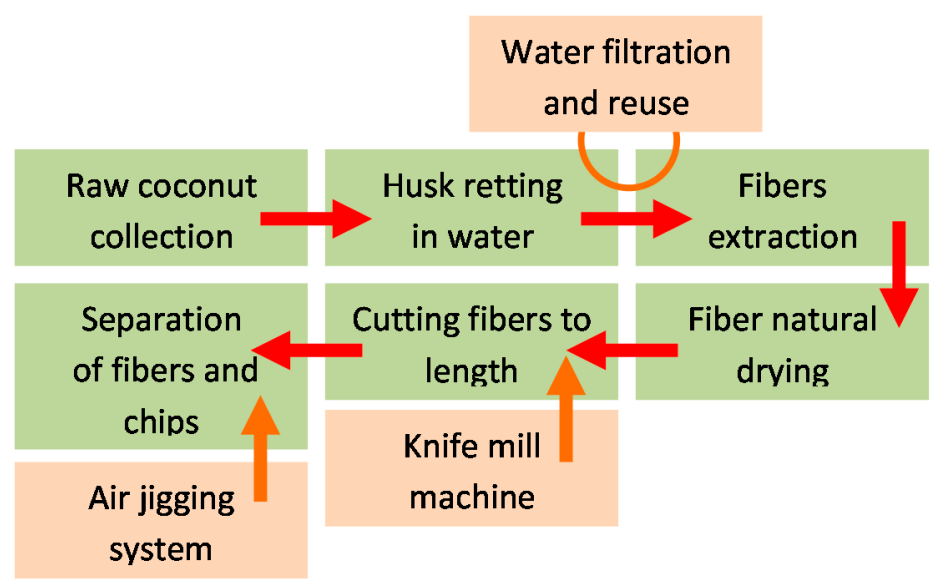

Figure 14. Eco-friendly method of coconut fibers preparation.

Author Contributions: H.B.: conceptualization, methodology, writing-review \& editing. N.S.: supervision and guidance of research work. M.B.: supervision and guidance of research work. D.L.: supervision, writing-review \& editing. All authors have read and agreed to the published version of the manuscript.

Funding: This research received no external funding.

Acknowledgments: The authors wish to thank Vietnam International Education Department (VIED) for financial support the PhD study of the first author under 911 program at ESITC Caen, France. We also thank David Lescarmontier for his technical assistance in all our experimental work. To improve the English language, we thank Ali Hussan and Mazhar Hussain for their help.

Conflicts of Interest: The authors declare no conflict of interest.

\section{References}

1. Liew, K.M.; Sojobi, A.O.; Zhang, L.W. Green concrete: Prospects and challenges. Constr. Build. Mater. 2017. [CrossRef]

2. Lertwattanaruk, P.; Suntijitto, A. Properties of natural fiber cement materials containing coconut coir and oil palm fibers for residential building applications. Constr. Build. Mater. 2015, 664-669. [CrossRef]

3. Verma, D.; Gope, P.C.; Shandilya, A.; Gupta, A.; Maheshwari, M.K. Coir fibre reinforcement and application in polymer composites: A review. J. Mater. Environ. Sci. 2013, 4, 263-276.

4. Abdullah, A.; Jamaludin, S.B.; Anwar, M.I.; Noor, M.M.; Hussin, K. Assessment of physical and mechanical properties of cement panel influenced by treated and untreated coconut fiber addition. Phys. Procedia 2011. [CrossRef]

5. Kanning, R.C.; Portella, K.F.; Bragança, M.O.G.P.; Bonato, M.M.; Santos, J.C.M.D. Banana leaves ashes as pozzolan for concrete and mortar of Portland cement. Constr. Build. Mater. 2014, 460-465. [CrossRef]

6. Bui, N.K.; Satomi, T.; Takahashi, H. Recycling woven plastic sack waste and PET bottle waste as fiber in recycled aggregate concrete: An experimental study. Waste Manag. 2018, 79-93. [CrossRef]

7. FAO. International Year of Natural Fibres. 2009. Available online: http://www.naturalfibres2009.org/ (accessed on 15 December 2017).

8. Abraham, E.; Deepa, B.; Pothen, L.A.; Cintil, J.; Thomas, S.; John, M.J.; Anandjiwala, R.; Narine, S.S. Environmental friendly method for the extraction of coir fibre and isolation of nanofibre. Carbohydr. Polym. 2013, 1477-1483. [CrossRef]

9. FAO. Jute, kenaf, sisal, abaca, coir and allied fibres. In Statistical Bulletin 2016; CCP: JU/HF/ST/2016/1, Market and Policy Analysis of Raw Materials, Horticulture and Tropical (RAMHOT) Products Team, Trade and Markets Division; Food and Agriculture Organization of the United Nations: Rome, Italy, 2017; 33p, Available online: http://www.fao.org/economic/futurefibres/resources2/en/ (accessed on 15 December 2017).

10. Munawar, S.S.; Umemura, K.; Kawai, S. Characterization of the morphological, physical, and mechanical properties of seven nonwood plant fiber bundles. J. Wood Sci. 2007, 108-113. [CrossRef] 
11. Sengupta, S.; Basu, G.; Chakraborty, R.; Thampi, C.J. Stochastic analysis of major physical properties of coconut fibre. Indian J. Fibre Text. Res. 2014, 39, 14-23.

12. Tran, L.Q.N.; Minh, T.N.; Fuentes, C.A.; Chi, T.T.; van Vuure, A.W.; Verpoest, I. Investigation of microstructure and tensile properties of porous natural coir fibre for use in composite materials. Ind. Crops Prod. 2015, 437-445. [CrossRef]

13. Yan, L.; Chouw, N.; Huang, L.; Kasal, B. Effect of alkali treatment on microstructure and mechanical properties of coir fibres, coir fibre reinforced-polymer composites and reinforced-cementitious composites. Constr. Build. Mater. 2016. [CrossRef]

14. Ramli, M.; Kwan, W.H.; Abas, N.F. Strength and durability of coconut-fiber-reinforced concrete in aggressive environments. Constr. Build. Mater. 2013, 554-566. [CrossRef]

15. Ezekiel, N.; Ndazi, B.; Nyahumwa, C.; Karlsson, S. Effect of temperature and durations of heating on coir fibers. Ind. Crops Prod. 2011, 638-643. [CrossRef]

16. Oda, S.; Fernandes, J.L.; Ildefonso, J.S. Analysis of use of natural fibers and asphalt rubber binder in discontinuous asphalt mixtures. Constr. Build. Mater. 2012, 13-20. [CrossRef]

17. Fidelis, M.E.A.; Pereira, T.V.C.; Gomes, O.D.F.M.; Silva, F.D.; Filho, R.D.T. The effect of fiber morphology on the tensile strength of natural fibers. J. Mater. Res. Technol. 2013, 149-157. [CrossRef]

18. Rana, S.; Fangueiro, R. Fibrous and textile materials for composite applications. In Textile Science and Clothing Technology; Springer: Singapore, 2016. [CrossRef]

19. Adekunle, K.F. Surface Treatments of Natural Fibres-A Review: Part 1. Open J. Polym. Chem. 2015, 41-46. [CrossRef]

20. Basu, G.; Mishra, L.; Jose, S.; Samanta, A.K. Accelerated retting cum softening of coconut fibre. Ind. Crops Prod. 2015, 66-73. [CrossRef]

21. Khan, G.M.A.; Alam, M.S.; Terano, M. Thermal characterization of chemically treated coconut husk fibre. Indian J. Fibre Text. Res. 2012, 37, 20-26.

22. da Silva, E.J.; Marques, M.L.; Velasco, F.G.; Junior, C.F.; Luzardo, F.M.; Tashima, M.M. A new treatment for coconut fibers to improve the properties of cement-based composites-Combined effect of natural latex/pozzolanic materials. Sustain. Mater. Technol. 2017. [CrossRef]

23. Sood, M.; Dwivedi, G. Effect of fiber treatment on flexural properties of natural fiber reinforced composites: A review. Egypt. J. Pet. 2017. [CrossRef]

24. Rodríguez, N.J.; Yáñez-Limón, M.; Gutiérrez-Miceli, F.A.; Gomez-Guzman, O.; Matadamas-Ortiz, T.P.; Lagunez-Rivera, L.; Feijoo, J.A.V. Assessment of coconut fibre insulation characteristics and its use to modulate temperatures in concrete slabs with the aid of a finite element methodology. Energy Build. 2011. [CrossRef]

25. Haque, M.M.; Hasan, M.; Islam, M.S.; Ali, M.E. Physico-mechanical properties of chemically treated palm and coir fiber reinforced polypropylene composites. Bioresour. Technol. 2009. [CrossRef] [PubMed]

26. Manohar, K. Experimental Investigation of Building Thermal Insulation from Agricultural By-products. Br. J. Appl. Sci. Technol. 2012, 227-239. [CrossRef]

27. Alavez-Ramirez, R.; Chiñas-Castillo, F.; Morales-Dominguez, V.; Ortiz-Guzman, M.; Lara-Romero, J. Thermal lag and decrement factor of a coconut-ferrocement roofing system. Constr. Build. Mater. 2014. [CrossRef]

28. Damfeu, J.C.; Meukam, P.; Jannot, Y. Modeling and measuring of the thermal properties of insulating vegetable fibers by the asymmetrical hot plate method and the radial flux method: Kapok, coconut, groundnut shell fiber and rattan. Thermochim. Acta 2016, 64-77. [CrossRef]

29. Danso, H. Properties of Coconut, Oil Palm and Bagasse Fibres: As Potential Building Materials. Procedia Eng. 2017, 1-9. [CrossRef]

30. Khedari, J.; Charoenvai, S.; Hirunlabh, J. New insulating particleboards from durian peel and coconut coir. Build. Environ. 2003, 38, 435-441. [CrossRef]

31. Babu, G.L.S.; Vasudevan, A.K. Strength and Stiffness Response of Coir Fiber-Reinforced Tropical Soil. J. Mater. Civ. Eng. 2008, 571-577. [CrossRef]

32. Hejazi, S.M.; Sheikhzadeh, M.; Abtahi, S.M.; Zadhoush, A. A simple review of soil reinforcement by using natural and synthetic fibers. Constr. Build. Mater. 2012, 100-116. [CrossRef]

33. Stevulova, N.; Estokova, A.; Cigasova, J.; Schwarzova, I.; Kacik, F.; Geffert, A. Thermal degradation of natural and treated hemp hurds under air and nitrogen atmosphere. J. Therm. Anal. Calorim. 2017, 1649-1660. [CrossRef] 
34. Laborel-Préneron, A.; Aubert, J.E.; Magniont, C.; Tribout, C.; Bertron, A. Plant aggregates and fibers in earth construction materials: A review. Constr. Build. Mater. 2016, 719-734. [CrossRef]

35. Amziane, S.; Collet, F.; Lawrence, M.; Magniont, C.; Picandet, V.; Sonebi, M. Recommendation of the RILEM TC 236-BBM: Characterisation testing of hemp shiv to determine the initial water content, water absorption, dry density, particle size distribution and thermal conductivity. Mater. Struct. Constr. 2017, 1-11. [CrossRef]

36. Sair, S.; Oushabi, A.; Kammouni, A.; Tanane, O.; Abboud, Y.; el Bouari, A. Mechanical and thermal conductivity properties of hemp fiber reinforced polyurethane composites. Case Stud. Constr. Mater. 2018, 203-212. [CrossRef]

37. Zimniewska, M.; Wladyka-Przybylak, M. Natural Fibers for Composite Applications. In Textile Science and Clothing Technology; Fibrous and Textile Materials for Composite Applications; Rana, S., Fangueiro, R., Eds.; Springer: Singapore, 2016. [CrossRef]

38. Afroz, M.; Patnaikuni, I.; Venkatesan, S. Chemical durability and performance of modified basalt fiber in concrete medium. Constr. Build. Mater. 2017, 191-203. [CrossRef]

39. Alavez-Ramirez, R.; Chiñas-Castillo, F.; Morales-Dominguez, V.J.; Ortiz-Guzman, M. Thermal conductivity of coconut fibre filled ferrocement sandwich panels. Constr. Build. Mater. 2012, 425-431. [CrossRef]

40. Hwang, C.L.; Tran, V.A.; Hong, J.W.; Hsieh, Y.C. Effects of short coconut fiber on the mechanical properties, plastic cracking behavior, and impact resistance of cementitious composites. Constr. Build. Mater. 2016. [CrossRef]

41. Nguyen, X.T.; Hou, S.; Liu, T.; Han, X. A potential natural energy absorption material—Coconut mesocarp: Part A: Experimental investigations on mechanical properties. Int. J. Mech. Sci. 2016. [CrossRef]

42. Sengupta, S.; Basu, G. Chapter 04122-Properties of Coconut Fiber, Ref. Modul. Mater. Sci. Mater. Eng. 2017, 1-20. [CrossRef]

43. Andiç-Çakir, Ö.; Sarikanat, M.; Tüfekçi, H.B.; Demirci, C.; Erdoğan, Ü.H. Physical and mechanical properties of randomly oriented coir fiber-cementitious composites. Compos. Part B Eng. 2014, 49-54. [CrossRef]

44. Liu, K.; Lu, L.; Wang, F.; Liang, W. Theoretical and experimental study on multi-phase model of thermal conductivity for fiber reinforced concrete. Constr. Build. Mater. 2017. [CrossRef]

45. Sindhu, K.; Joseph, K.; Joseph, J.M.; Mathew, T.V. Degradation studies of coir fiber/polyester and glass fiber/polyester composites under different conditions. J. Reinf. Plast. Compos. 2007, 1571-1585. [CrossRef]

46. Asasutjarit, C.; Hirunlabh, J.; Khedari, J.; Charoenvai, S. Development of coconut coir-based lightweight cement board. Constr. Build. Mater. 2007, 277-288. [CrossRef]

47. Hasan, N.M.; Sobuz, H.R.; Sayed, M.S.; Islam, M.S. The use of coconut fiber in the production of structural lightweight concrete. Appl. Sci. 2012, 12, 831-839.

48. Asasutjarit, C.; Charoenvai, S.; Hirunlabh, J.; Khedari, J. Composites: Part B Materials and mechanical properties of pretreated coir-based green composites. Compos. Part B 2009, 633-637. [CrossRef]

49. Ferreira, S.R.; Silva, F.D.A.; Lima, P.R.L.; Filho, R.D.T. Effect of fiber treatments on the sisal fiber properties and fiber-matrix bond in cement based systems. Constr. Build. Mater. 2015, 730-740. [CrossRef]

50. Arsyad, M.; Wardana, I.; Irawan, Y.S. The morphology of coconut fiber surface under chemical treatment. Rev. Mater. 2015, 169-177. [CrossRef]

51. Rawangkul, R.; Khedari, J.; Hirunlabh, J.; Zeghmati, B. Characteristics and performance analysis of a natural desiccant prepared from coconut coir. ScienceAsia 2010, 216-222. [CrossRef]

52. Pacheco-Torgal, F.; Jalali, S. Cementitious building materials reinforced with vegetable fibres: A review. Constr. Build. Mater. 2011, 575-581. [CrossRef]

53. Page, J.; Khadraoui, F.; Boutouil, M.; Gomina, M. Multi-physical properties of a structural concrete incorporating short flax fibers. Constr. Build. Mater. 2017, 344-353. [CrossRef]

54. Sen, T.; Reddy, H.N.J. Application of sisal, bamboo, coir and jute natural composites in structural upgradation. Int. J. Innov. Manag. Technol. 2011, 186-191. [CrossRef]

55. Millogo, Y.; Aubert, J.E.; Hamard, E.; Morel, J.C. How properties of kenaf fibers from Burkina Faso contribute to the reinforcement of earth blocks. Materials 2015, 2332-2345. [CrossRef]

56. Pinto, J.; Cruz, D.; Paiva, A.; Pereira, S.; Tavares, P.; Fernandes, L.; Varum, H. Characterization of corn cob as a possible raw building material. Constr. Build. Mater. 2012, 28-33. [CrossRef]

57. Asdrubali, F.; D'Alessandro, F.; Schiavoni, S. A review of unconventional sustainable building insulation materials. Sustain. Mater. Technol. 2015, 1-17. [CrossRef] 
58. Guillou, J.; Lavadiya, D.N.; Munro, T.; Fronk, T.; Ban, H. From lignocellulose to biocomposite: Multi-level modelling and experimental investigation of the thermal properties of kenaf fiber reinforced composites based on constituent materials. Appl. Therm. Eng. 2018, 1372-1381. [CrossRef]

59. $\mathrm{Gu}, \mathrm{H}$. Tensile behaviours of the coir fibre and related composites after $\mathrm{NaOH}$ treatment. Mater. Des. 2009, 3931-3934. [CrossRef]

60. Baley, C. Analysis of the flax fibres tensile behaviour and analysis of the tensile stiffness increase. Compos. Part A Appl. Sci. Manuf. 2002, 939-948. [CrossRef]

61. Kumar, S.M.S.; Duraibabu, D.; Subramanian, K. Studies on mechanical, thermal and dynamic mechanical properties of untreated (raw) and treated coconut sheath fiber reinforced epoxy composites. Mater. Des. 2014, 63-69. [CrossRef]

62. Kabir, M.M.; Wang, H.; Lau, K.T.; Cardona, F. Chemical treatments on plant-based natural fibre reinforced polymer composites: An overview. Compos. Part B Eng. 2012, 2883-2892. [CrossRef]

63. Li, Y.; Mai, Y.W.; Ye, L. Sisal fibre and its composites: A review of recent developments. Compos. Sci. Technol. 2000, 2037-2055. [CrossRef]

64. Wei, J.; Meyer, C. Improving degradation resistance of sisal fiber in concrete through fiber surface treatment. Appl. Surf. Sci. 2014, 511-523. [CrossRef]

65. Wei, J.; Meyer, C. Degradation mechanisms of natural fiber in the matrix of cement composites. Cem. Concr. Res. 2015, 1-16. [CrossRef]

66. Yang, H.; Yan, R.; Chen, H.; Lee, D.H.; Zheng, C. Characteristics of hemicellulose, cellulose and lignin pyrolysis. Fuel 2007, 1781-1788. [CrossRef]

(C) 2020 by the authors. Licensee MDPI, Basel, Switzerland. This article is an open access article distributed under the terms and conditions of the Creative Commons Attribution (CC BY) license (http://creativecommons.org/licenses/by/4.0/). 